\title{
Cleaner Production in Order to Save the Health of Human and Environment: A Review
}

\section{Sherani $\mathrm{SH}^{*}$}

Department of Environmental Sciences, Sardar Bahadur Khan Women's University, Pakistan

*Corresponding author: Sadia Hassan Sherani, Department of Environmental Sciences, Sardar Bahadur Khan Women's University Quetta, Balochistan, Pakistan, Email: sadiasherani.333@ gmail.com

\section{Review Article}

Volume 3 Issue 1

Received Date: January 17, 2020

Published Date: February 10, 2020

DOI: $10.23880 /$ jqhe-16000151

\section{Abstract}

The present review paper highlights the concept of cleaner production in order to save the health of human and environment. Cleaner production is a practical method that is implemented in an organization to reduce the damages and risks towards humans and environment. CP promotes the concept of sustainable development in which we consider economy and environment both together. Production in which we don't consider impacts on human health and environment always create some major problems or issues. To create more sustainable methods of production, there needs to be a shift in attitudes and behavior towards sustainable development or pollution free production. Cleaner production focuses on a new way about processes, products and services to find better way to minimize the impacts on human health and environment. Companies/ organizations that follow the concept of sustainable development in their production always gain the confidence of public and improve the public image towards them. Moreover, CP improves the company performance, Makes companies more profitable and competitive and reduces the overall emission level of pollutants into the air, water and soil and maximizes the product output.

Keywords: Cleaner production; Human Health; Environment; Economic Growth; Technology

Abbreviations: CP: Cleaner Production; UNEP: United Nations Environmental Programme; UNIDO: United Nations Industrial Development Organization; DTIE: Division Of Technology, Industry and Environment.

\section{Introduction}

The term cleaner production was coined by the United Nations Environmental programme, Division of technology, Industry and Environment (UNEP's DTIE) during the Rio summit in 1989. In 1994, UNIDO (United Nations industrial development organization) and UNEP both jointly initiated the worldwide national CP center programme (UNIDO CP programme, 2002). National cleaner production centers and programmes were operated by UNIDO with centers in
Africa, Latin America, Asia and Europe. According to UNEP, $\mathrm{CP}$ is defined as the continuous application of an integrated preventive environmental strategy towards or applied to processes, products and services in order to increase the overall efficiency and reduce the damages and risks towards humans and environment [1].

\section{Options/Practices/Approaches in cleaner production}

Different options, practices and techniques are done in cleaner production that includes;

Input material substitution: Input material substitution includes replacing of toxic materials into less toxic materials. Use renewable materials rather than using non-renewable 
materials and use these types of materials that have longer lifetime [2].

Technology change: Technology change includes replacing of equipments, equipments modification, improved process control, increased automation and improved equipment layout [2].

Good / improved operation practice: Good operation practice includes proper Product scheduling, Energy management and Maintenance programmes, working instructions and procedures, Training and incentives programs, adequate process control operations, Proper maintenance and cleaning [2]

Product modification: Product modification includes recycling of product into friendly design, Product life extension, use of more efficient products, less material intensive packing and reduction of harmful substances [2].

Reuse and recycling: Reuse and recycling includes Onsite recovery and reuse of raw material in the process, waste water, waste heat and cooling water, Transformations of waste into useful by products, Proper waste segregation and storage [2].

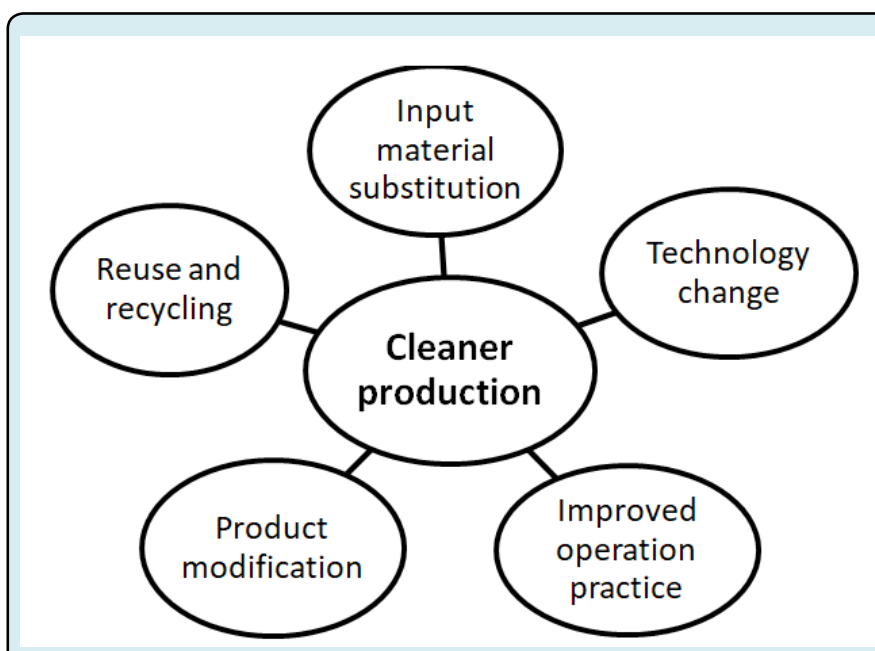

Figure 1: Cleaner production practices/options.

Cleaner production in order to save human health and environment: Cleaner production is a practical method that saves the health of human and environment [3]. The current way of our production either making products or organizing services both harming our environment in several ways and creates a number of health issues/problems. Every product contains or has a life cycle which includes raw material extraction, transport of material towards production sites, manufacturing, packaging, tarnsport of final product, sales, services and disposal. $\mathrm{CP}$ is that type of practice that reduced/minimized the impacts throughout the product life cycle [4]. The goal of cleaner production is to create a cradle-to-cradle process with mimimum negative imapct and miximum positive impact on the health of human and envirenment [5]. Cleaner production protects human health and environment, miximize product output, reduce impacts, conserve raw materials, eliminate toxic subtances and reduce overall emissions. Implementation of cleaner production in an organization not only provides environmental benefits but also provides economical benefits. Cleaner production must be implemented in an organization to save the earth from future threats [6-11].

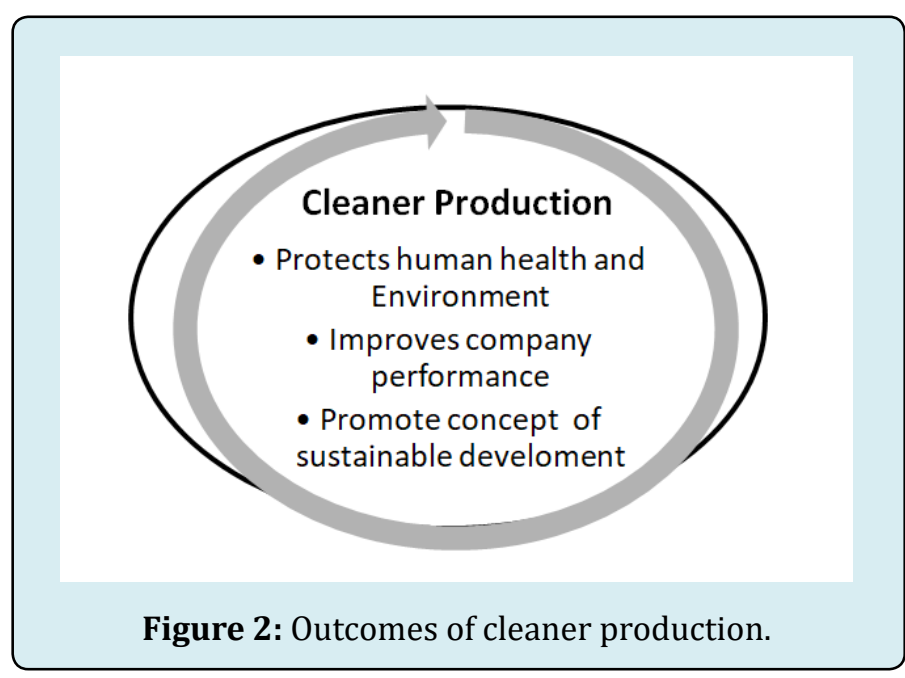

Benefits of cleaner production: The benefits of cleaner production includes, Improves products and services, Lower the risks(liability), Improves workers health and safety conditions, Reduces waste treatment and disposal cost, Reduce costs on raw material, energy and water, Makes companies more profitable and competitive, Increase resource efficiency of production, Better use of materials and energy, Reduce health safety and environmental damage cost, Improve companies performance, Help companies to comply with environmental protection regulations, Better quality of products and Reduced risks towards human health, environment [12-15].

\section{Conclusion}

Production in which we don't consider the impacts of production on human health and environment will always create some major problems/impacts. These major problems or impacts include environmental pollution, health problems and some global/large scale impacts. To create more sustainable methods of production, there needs to be a shift in attitudes and behavior towards sustainable development or pollution free production. Human behavior/ attitude is a very important component for the protection of environment. First change the behavior or attitude of an individual to solve the major problems/issues. As people are aware about certain issues that results from production 
they will work together in sustainable manner to reduce the impacts and promote the concept of cleaner production to save present and future of individuals. Cleaner production activities include some measures that are source reduction, pollution prevention, waste minimization and eco-efficiency. Companies/organization that follow the concept of sustainable development will always gain the confidence of public and improve the public image towards them.

"We Learned That Economic Growth and Environmental Protection Can and Should Go Hand In Hand" (Christopher Dodd).

\section{References}

1. Fresner J (1998) Starting Continuous improvement starting with a cleaner production assessment in Austrian textile mill. Journal of cleaner production 6(2): 85-91.

2. Ghazinoory S (2005) Cleaner production in Iran. Journal of cleaner production 13(8): 755-762.

3. Demirer GN (2006) Cleaner production opportunity assessment study in SEKA Balikisir pulp and paper mill. Journal of cleaner production 16(4): 1-10.

4. Dunn RF, Bush GE (2001) Using process integration for cleaner production. Journal of cleaner production 9(1): 1-13.

5. Salah M, El-Haggar PE (2007) Sustainable Industrial Design and Waste Management. Chapter 2. Cleaner production pp: 21-84.

6. Gale R (2006) Environmental management accounting as a reflexive modernization strategy in cleaner production.
Journal of cleaner production 14(14): 1228-1236.

7. Ghorbannezhad P, Majid Azizi, Ting SC, Ramezani O (2010) Cleaner production; a case study of kavech paper mill. International Journal of sustainable engineering $\mathrm{pp}$ : 68-74.

8. Hens L, Block C, Cabello Erascd JJ, Gutierezc S, Lorenzod $G$, et al. (2018) On the evolution of cleaner production as a concept and a practice. Journal of cleaner production 172: 3323-3333.

9. Mass (2014) Integrating corporate sustainability performance measurement, management and reporting. Journal of cleaner production 65: 7-8.

10. Narayanaswamy V, Stone L (2007) From cleaner production to sustainable production and consumption in Australia and New Zealand. Journal of cleaner production 15(8-9): 711-715.

11. World Bank group. Cleaner production.

12. Sustainability concepts: Cleaner production-GDRC.

13. (2020) Cleaner production-an overview/science direct topic.

14. Balkau F (2005) International frameworks for environmental solutions. Environmental Solutions pp: 401-434.

15. Nilsson L, Persson PO, Ryden L, Darozhka S, Zaliauskiene A (2007) Cleaner Production Technologies and Tools for Resource Efficient Production. Book 2 in a series on Environmental Management. The Baltic University Press, Nina Tryckeri, Uppsala 2007, Sweden, ISBN 91975526-1-5. 